\title{
THE IMPACT OF THE MODEL FOR END-STAGE LIVER DISEASE (MELD) ON LIVER TRANSPLANTATION IN ONE CENTER IN BRAZIL
}

\author{
Alexandre Coutinho Teixeira de FREITAS, William Massami ITIKAWA, \\ Adriana Sayuri KUROGI, Lucinei G. STADNIK, Mônica Beatriz PAROLIN and \\ Júlio Cezar Uili COELHO
}

\begin{abstract}
Context - Presently the MELD score is used as the waiting list criterion for liver transplantation in Brazil. In this method more critical patients are considered priority to transplantation. Objective - To compare the results of liver transplantation when the chronologic waiting list was the criterion for organ allocation (pre-MELD era) with MELD score period (MELD era) in one liver transplantation unit in Brazil. Methods - The charts of the patients subjected to liver transplantation at the Hospital de Clínicas da Universidade Federal do Paraná, Curitiba, PR, Brazil, were reviewed from January of 2001 to August of 2008. Patients were divided into two groups: pre-MELD era and MELD era. They were compared in relation to demographics of donors and receptors, etiology of cirrhosis, cold and warm ischemia time, presence of hepatocellular carcinoma, MELD score and Child-Pugh score and classification at the time of transplantation, units of red blood cells transfused during the transplantation, intensive care unit stay, total hospital stay and 3 month and 1 year survival. Results - Initially, 205 liver transplantations were analyzed. Ninety four were excluded and 111 were included: 71 on the pre-MELD era and 40 on the MELD era. The two groups were comparable in relation to donors and receptors age and sex, etiology of cirrhosis and cold and warm ischemia time. The receptors of the MELD era had more hepatocellular carcinoma than those of the pre-MELD era (37.5\% vs $16.9 \%)$. Patients with hepatocellular carcinoma had less advanced cirrhosis on both eras. The MELD score was the same on both eras. Excluding the cases of hepatocellular carcinoma, MELD era score was higher than pre-MELD score (18.2 vs 15.8). There were an increased number of transplants on Child-Pugh A and $\mathrm{C}$ and a decreased number on Child-Pugh B receptors on MELD era. Both eras had the same need of red blood cells transfusion, intensive care unit stay and hospital stay. Also, 3 month and 1 year survival were the same: $76 \%$ and $74.6 \%$ on pre-MELD era and $75 \%$ and $70.9 \%$ on MELD era. Conclusion - In our center, after the introduction of MELD score as the priority criterion for liver transplantation there were an increased number of transplants with hepatocellular carcinoma. Excluding these patients, the receptors were operated upon with more advanced cirrhosis. Nevertheless the patients had the same need for red blood cells transfusion, intensive care unit and hospital stay and 3 months and 1 year survival.
\end{abstract}

HADINGS - Liver transplantation. Carcinoma, hepatocellular. Liver cirrhosis. Waiting lists. Survival analysis.

\section{INTRODUCTION}

End-stage liver disease is considered one of the major causes of death in the United States and its treatment is a major public health dilemma. There were 27,530 deaths related to end-stage liver disease $(9.3$ deaths per 100,000 persons) in $2005^{(6)}$. The treatment of choice for selected end-stage liver disease patients is liver transplantation. In the last years the number of individuals listed for transplantation increased more than the number of transplants performed ${ }^{(23)}$. In Brazil, 564 liver transplantations were done in $2001^{(1)}$.
In 2008 it had a 2 fold increase to 1175 transplants. But the number of patients on waiting list had a 2.5 fold increase, from 2,539 to 6,505 patients on the same period $^{(1)}$. This has caused an increase in waiting time and mortality of candidates to liver transplant ${ }^{(23)}$. One Brazilian liver transplantation center has shown a 20\% mortality for patients on waiting list ${ }^{(4)}$. Other study has shown $12 \%$ mortality rate for 3 -month waiting list ${ }^{(24)}$.

The model for end-stage liver disease (MELD) was introduced in Brazil for organ allocation in 2006. This model assess the severity of cirrhosis and predicts mortality ${ }^{(5,7,15,20)}$. It gives priority to

Liver Transplantation Unit, Hospital de Clínicas da Universidade Federal do Paraná, Curitiba, PR, Brazil

This study had no financial support

Correspondence: Dr. Alexandre Coutinho Teixeira de Freitas - Avenida República Argentina, 210 - $4^{\circ}$ andar - 80240-210 - Curitiba, PR, Brazil. E-mail: alexandrefreitas@ufpr.br 
candidates to transplant with more severe disease. It also prioritizes patients with hepatocellular carcinoma. Before the MELD was introduced, organ allocation was based on chronological waiting time.

Following the introduction of MELD in the United States in 2001, many transplantation centers have shown reduction of mortality rates for candidates on waiting list $t^{(9,16)}$. However, some surgeons have hypothesized that the MELD model could increase the transplantation morbidity and mortality, since this system gives priority to candidates with more severe cases of cirrhosis. Only a few data were published in Brazil evaluating liver transplantation complications after the introduction of the MELD.

This study aimed to compare the results of liver transplantation before and after the introduction of the MELD in one Brazilian center.

\section{METHODS}

The charts of all patients subjected to liver transplantation at the Hospital de Clínicas, Universidade Federal do Paraná, Curitiba, PR, Brazil, between January of 2001 and August of 2008 were reviewed. They were divided into two groups according to the period in which the transplant was done: pre-MELD era, for the transplants done from January 2001 to June of 2006, when the criterion for organ allocation was the chronological time, and MELD era, from July of 2006 to August of 2008, when the criterion for organ allocation was the MELD score.

The following information were collected from the receptors: sex, age, etiology of cirrhosis, presence of hepatocellular carcinoma, MELD score and Child-Pugh classification at the time of the transplantation, warm ischemia time, units of red blood cells transfused during the transplantation, intensive care unit (ICU) stay, hospital stay, 3-month and 1-year cumulative survival after the transplantation. The MELD score on MELD era was represented without considering the extra points conferred in patients with hepatocellular carcinoma. The following information was collected from the donors: sex, age and cold ischemia time. In relation to the etiology of the cirrhosis the patients were divided into three groups: cholestatic diseases, hepatitis $\mathrm{C}$ and other etiologies. On cholestatic diseases group were included the cases of primary biliary cirrhosis, primary sclerosing cholangitis and secondary biliary cirrhosis. On other etiologies were included alcoholic cirrhosis, hepatitis B, autoimmune hepatitis, cryptogenic cirrhosis, alpha-1 antitrypsine deficiency, and association of hepatitis B and alcoholic cirrhosis. Comparison of all this information was done between the pre-MELD and the MELD eras.

The survival analysis was done as follows: a) comparing pre-MELD and MELD eras; comparing pre-MELD and MELD eras excluding patients with hepatocellular carcinoma; comparing patients with hepatocellular carcinoma with patients without hepatocellular carcinoma on pre-MELD era and also on MELD era.
The exclusion criteria were: incomplete charts, transplants done for other reasons than liver cirrhosis, pediatric liver transplants, living-related liver transplantation and multiple organ transplantations.

The statistical analysis was done with the Kaplan-Meier method and the Log-Rank test for cumulative survival. The comparison between pre-MELD and MELD eras for the other data was done with the $t$-test for mean values and the chi-square test for proportions. It was considered the level of $5 \%$ for significance $(P \leq 0.05)$.

\section{RESULTS}

Initially, 205 liver transplantations were analyzed. Ninety four cases were excluded: 75 due to incomplete charts, 4 pediatric liver transplantations, 2 fulminant hepatic failures, 6 living-related liver transplantations, 5 retransplants for hepatic artery thrombosis and 2 simultaneous liver and kidney transplantations. One hundred and eleven cases were included: 71 in the pre-MELD era and 40 in the MELD era. The sex and age distribution and the etiology of cirrhosis were the same on both eras (Table 1). Females were younger than males, both in the pre-MELD era (43.8 \pm 14 vs $52.7 \pm 10$ years) $(P=0.002)$ and in the MELD era $37.5 \pm 14$ vs $48.9 \pm$ 10 years $)(P<0.001)$. Most of the donors were male: $71.8 \%$ in the pre-MELD era and $65 \%$ in the MELD era. There was no difference between the two eras in relation to donor age $(35.3 \pm 13$ for the pre-MELD era vs $31.8 \pm 14$ years for the MELD era) and cold and warm ischemia time.

TABLE 1. Patient distribution according to sex, age and etiology of cirrhosis

\begin{tabular}{lccc}
\hline & Pre-MELD era & MELD era & $P$ \\
\hline $\mathrm{n}$ & 71 & 40 & - \\
$\mathrm{Sex}$ & & & \\
$\quad$ Female & $25(35.2 \%)$ & $9(22.5 \%)$ & 0.1 \\
$\quad$ Male & $46(64.8 \%)$ & $31(77.5 \%)$ & 0.1 \\
Age & $49.6 \pm 12$ & $46.3 \pm 12$ & \\
Etiology of cirrhosis & & & \\
$\quad$ Cholestatic diseases* & $5(7 \%)$ & $2(5 \%)$ & 0.1 \\
$\quad$ Hepatitis C & $31(43.7 \%)$ & $11(27.5 \%)$ & \\
$\quad$ Other etiologies** & $35(49.3 \%)$ & $27(67.5 \%)$ & \\
* = Primary biliary cirrhosis, primary sclerosing cholangitis and secondary biliary cirrhosis; \\
** Alcoholic cirrhosis, hepatitis B, autoimmune hepatitis, cryptogenic cirrhosis, alpha-1 antitrypsine deficiency, and association \\
of hepatitis B and alcoholic cirrhosis
\end{tabular}

There was an increase in the number of transplantations done in patients with hepatocellular carcinoma (Table 2). In the pre-MELD era $16.9 \%$ of receptors had hepatocellular carcinoma and in the MELD era $37.5 \%(P=0.01)$. There was no difference in the general MELD score between the two eras (Table 2). The MELD score of patients with hepatocellular carcinoma was also the same (Table 2). The MELD score of patients without hepatocellular carcinoma was $18.2 \pm 6$ in the MELD era (Table 2), this value was higher than the MELD score in the pre-MELD era (15.8 $\pm 4)$. In the pre-MELD era patients without hepatocellular carcinoma had MELD score higher than patients with hepatocellular carcinoma (Table 2 ). The same was observed in the MELD era (Table 2). The Child-Pugh score was 
also the same in both eras (Table 2) but the distribution of Child-Pugh classes was different. In the MELD era it was observed an increase in the number of Child-Pugh $\mathrm{A}$ and $\mathrm{C}$ and a decrease in the number of Child-Pugh B patients (Table 2). The analysis of patients without hepatocellular carcinoma showed the same score and distribution of classes in both eras (Table 2).

TABLE 2. Receptors data

\begin{tabular}{|c|c|c|c|}
\hline & Pre-MELD era & MELD era & $P$ \\
\hline Patients with $\mathrm{HCC}-\mathrm{n}(\%)$ & $12(16.9 \%)$ & $15(37.5 \%)$ & 0.01 \\
\hline Average MELD score & $15.1 \pm 4$ & $16 \pm 6$ & 0.3 \\
\hline Patients with HCC & $11.4 \pm 2 *$ & $12.3 \pm 3 * *$ & 0.4 \\
\hline Patients without HCC & $15.8 \pm 4 *$ & $18.2 \pm 6 * *$ & 0.03 \\
\hline \multicolumn{4}{|l|}{ Child-Pugh classification } \\
\hline Average score & $8.4 \pm 1$ & $8.3 \pm 2$ & 0.7 \\
\hline Child A - n $(\%)$ & $6(8.5 \%)$ & $7(17.5 \%)$ & \multirow{3}{*}{$<0.001$} \\
\hline Child B - n $(\%)$ & $49(69.1 \%)$ & $21(52.5 \%)$ & \\
\hline Child $\mathrm{C}-\mathrm{n}(\%)$ & $16(22.4 \%)$ & $12(30 \%)$ & \\
\hline \multicolumn{4}{|l|}{$\begin{array}{l}\text { Child-Pugh classification } \\
\text { (patients without HCC) }\end{array}$} \\
\hline Average score & $8.7 \pm 1$ & $9 \pm 1$ & \multirow{2}{*}{0.5} \\
\hline Child A $-\mathrm{n}(\%)$ & $2(3.4 \%)$ & $1(4 \%)$ & \\
\hline Child B - n $(\%)$ & $41(69.5 \%)$ & $13(52 \%)$ & \multirow{2}{*}{0.3} \\
\hline Child $\mathrm{C}-\mathrm{n}(\%)$ & $16(27.1 \%)$ & $11(44 \%)$ & \\
\hline Average units of red blood cells transfunded & $4.6 \pm 3$ & $3.9 \pm 3$ & 0.2 \\
\hline Patients with HCC & $5.7 \pm 6$ & $3.6 \pm 4$ & 0.2 \\
\hline Patients without HCC & $4.4 \pm 2$ & $4 \pm 2$ & 0.5 \\
\hline ICU stay (days) & $4.7 \pm 7$ & $4.6 \pm 6$ & 0.9 \\
\hline Patients with HCC & $4.2 \pm 4$ & $3.3 \pm 3$ & 0.5 \\
\hline Patients without HCC & $5 \pm 7$ & $5.4 \pm 7$ & 0.7 \\
\hline Hospital stay (days) & $16.6 \pm 13$ & $15.3 \pm 8$ & 0.6 \\
\hline Patients with HCC & $17 \pm 8$ & $12.4 \pm 5$ & 0.1 \\
\hline Patients without HCC & $16.5 \pm 14$ & $17.4 \pm 10$ & 0.9 \\
\hline
\end{tabular}

Red blood cells transfusion, ICU stay and hospital stay were similar in both eras (Table 2). This was also observed in the analysis of patients with and without hepatocellular carcinoma.

Figures 1 and 2 show 3-month and 1-year cumulative survival. Three-month cumulative survival was $76 \%$ in the pre-MELD era and $75 \%$ in the MELD era $(P=0.9)$. Oneyear cumulative survival was $74.6 \%$ in the pre-MELD and $70.9 \%$ in the MELD era $(P=0.6)$. Excluding patients with hepatocellular carcinoma the 3-month cumulative survival was $72.8 \%$ in pre-MELD era and $68 \%$ in the MELD era $(P$ $=0.6$ ). The 1 -year cumulative survival was $69.4 \%$ and $57.8 \%$ $(P=0.3)$. In the pre-MELD era, patients with hepatocellular carcinoma had higher cumulative survival than patients without hepatocellular carcinoma: 3-month survival was $100 \%$ vs $72.8 \%(P=0.04)$ and 1 -year survival was $100 \%$ vs $69.4 \%(P=0.02)$. In the MELD era the 3-month cumulative survival was the same, $86.6 \%$ vs $68 \%(P=0.2)$; but the 1 -year cumulative survival was higher in patients with hepatocellular carcinoma, $91.6 \%$ vs $57.8 \%(P=0.04)$. Nine cases in the MELD era were excluded of the survival analysis because they did not completed 1 year of follow-up.

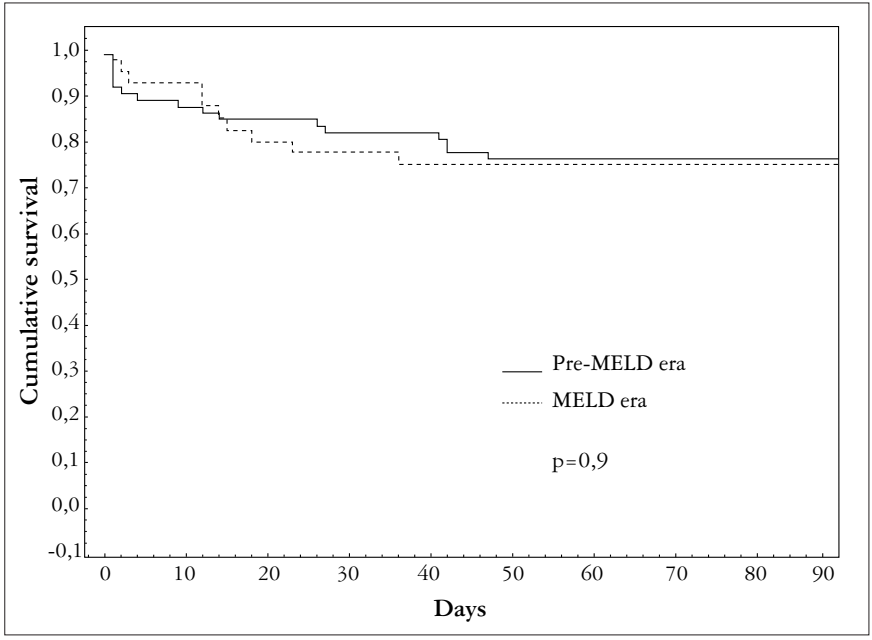

FIGURE 1. Three month cumulative survival of PRE-MELD era vs MELD era

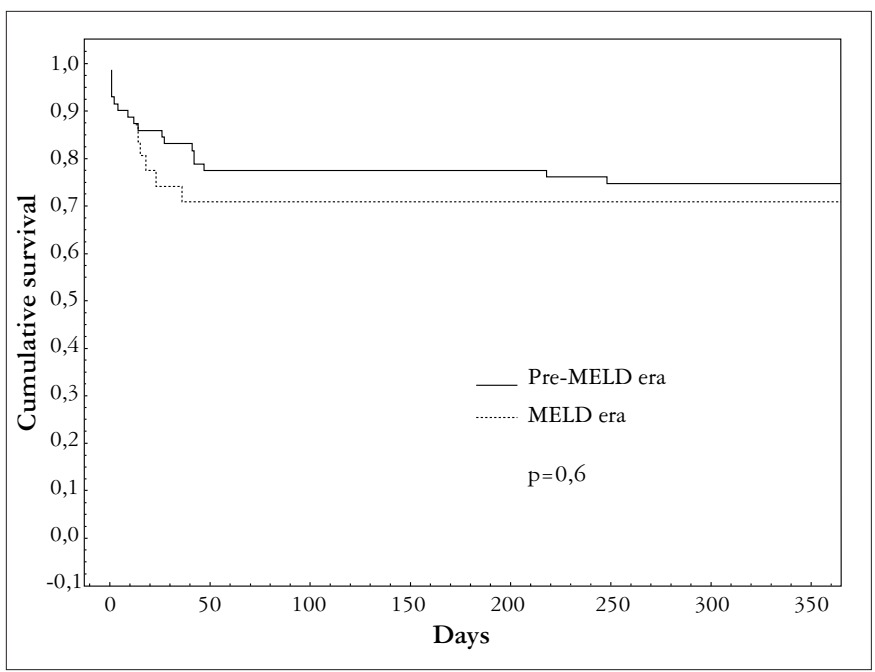

FIGURE 2. One year cumulative survival of PRE-MELD era vs MELD era

\section{DISCUSSION}

MELD score was originally developed to select candidates to TIPS (transjugular intrahepatic portosystemic shunt) ${ }^{(12,18)}$. Over time it has been demonstrated to be an excellent predictor of morbidity and mortality of cirrhotic patients ${ }^{(24)}$. MELD score is superior to Child-Pugh classification because it considers only objective parameters: bilirrubin, INR and creatinin ${ }^{(8,15)}$.

Many authors have shown that MELD score also proved to predict morbidity and mortality after liver transplantation ${ }^{(11,16 \text {, }}$ 18). One study divided 1,472 patients into 3 groups according to MELD score: from 6 to 15,16 to 25 and higher than 25 . Posttransplant survival was different between the groups. One year survival was $86 \%, 85 \%$ and $75 \%$ and 10 year survival was $62 \%$, $59 \%, 45 \%$, respectively ${ }^{(11)}$. Other study with 8,102 patients showed that an increase of 10 points on MELD score is associated to $39 \%$ increment on 1 year mortality after liver transplantation ${ }^{(16)}$. 
The MELD score was introduced in Brazil in 2006 as liver allocation criterion. The idea was to transplant patients with more severe disease and reduce waiting list mortality. If one accepts that higher MELD scores are associated to worse prognosis, one could speculate that higher scores could decrease the short term survival after liver transplantation. In this study we did not observe differences in 3 month and 1 year survival comparing pre-MELD and MELD eras. Furthermore, indicators of complications or worse evolution, as units of red blood cell transfused, ICU and hospital stay, were similar in both groups. We have to consider that the general MELD score was the same between the two eras. Excluding patients with hepatocellular carcinoma we observed higher MELD score on MELD era. This difference was very small and the 3 month and 1 year cumulative survival rates were also the same in the two groups.

In Brazil, patients with cirrhosis and hepatocellular carcinoma are listed to liver transplantation according to Milan criteria: 1 nodule of less than $5 \mathrm{~cm}$ in diameter or a maximum of 3 nodules, each one less of $3 \mathrm{~cm}$ in diameter ${ }^{(19)}$. To avoid tumor growth beyond Milan criteria while the patient is on waiting list, extra points are added on MELD score. Therefore, some patients with hepatocellular carcinoma are transplanted earlier in the evolution of cirrhosis. According to Brazilian legislation, patients with hepatocellular carcinoma receive initially 20 points extra on MELD score. This value is added to MELD score calculated from bilirrubin level, INR and creatinin level. The resulting value is determinant on waiting list ordering. This is the reason why in this study we have observed an increase in the number of liver transplantations in patients with hepatocellular carcinoma on MELD era in relation to pre-MELD era. In other countries, the mortality on waiting list decreased and the number of transplants of patients with hepatocellular carcinoma also increased after adoption of the MELD score as criterion to liver allocation ${ }^{(2,21,25)}$.

In this study, patients with hepatocellular carcinoma of the MELD era were transplanted with lower stage of the Child-Pugh classification than patients without hepatocellular carcinoma. The same happened with the MELD score if extra points are not considered in patients with hepatocellular carcinoma. But on pre-MELD era, when patients with hepatocellular carcinoma did not received extra points, they also presented with lower MELD score. The reason is that patients with hepatocellular carcinoma are referred to liver transplantation earlier, when the procedure would not be indicated only due to the stage of cirrhosis. The fact that patients with hepatocellular carcinoma are transplanted in less advanced stage of cirrhosis reflects in less morbidity and mortality. We have previously shown a better 3 month and 1 year cumulative survival in patients with hepatocellular carcinoma in the pre-MELD era ${ }^{(10)}$. In this study this was also observed in the pre-MELD era and for 1 year survival in the MELD era. United Network for Organ Sharing - UNOS data have shown the same 1 year survival for patients with and without hepatocellular carcinoma ${ }^{(22)}$. Other authors have shown good short time survival after liver transplantation in patients with hepatocellular carcinoma ${ }^{(3,13,14,17,19,26)}$. The 1 year cumulative survival ranged from $70 \%$ to $90 \%$.

Considering that patients with hepatocellular carcinoma must be assessed apart because they receive extra points and are transplanted with less severe cirrhosis we analyzed the MELD score excluding these patients. We have observed that transplant was done in patients with higher MELD score in the MELD era than in the pre-MELD era. Also, even including patients with hepatocellular carcinoma, we have observed changes on Child-Pugh distribution. There were increase in the number of Child-Pugh $\mathrm{A}$ and $\mathrm{C}$ and decrease in the number of Child-Pugh B patients. This distribution reflects the increased number of hepatocellular carcinoma transplanted, that are mostly Child-Pugh class A, and the increased number of more severe cirrhotic patients transplanted in the MELD era, that are mostly patients without hepatocellular carcinoma.

\section{CONCLUSION}

In our center, after the introduction of MELD score as priority criterion for liver transplantation, it was observed increase in the number of transplant of patients with hepatocellular carcinoma. Excluding the cases of hepatocellular carcinoma, the transplants were done in patients with more advanced cirrhosis. There was no increase in the indicators of worse prognosis or complications after the transplantation and there was no change in the 3-month and 1-year post-transplant survival rate. 
Freitas ACT, Itikawa WM, Kurogi AS, Stadnik LG, Parolin MB, Coelho JCU. O impacto do MELD no transplante de fígado em um centro no Brasil. Arq Gastroenterol. 2010;47(3):233-7.

RESUMO - Contexto - Atualmente o MELD é utilizado no Brasil como critério de seleção de receptores na lista de espera para transplante hepático. Esse sistema prioriza para o transplante os pacientes com cirrose hepática mais avançada. Objetivo-comparar os resultados do transplante hepático quando o tempo em lista de espera era o critério de alocação de órgãos (era pré-MELD) em relação ao período em que se utiliza o MELD (era MELD). Métodos Foram revisados os prontuários dos pacientes submetidos a transplante hepático no Hospital de Clínicas da Universidade Federal do Paraná no período de janeiro de 2001 até agosto de 2008. Os pacientes foram divididos em dois grupos: era pré-MELD e era MELD. Foram comparados em relação aos dados demográficos dos doadores e dos receptores, à etiologia da cirrose, ao tempo de isquemia morna e fria, à presença de carcinoma hepatocelular, ao escore do MELD e ao escore e à classificação de Child-Pugh no momento do transplante, às unidades de concentrado de plaquetas transfundidas durante o transplante, ao tempo de permanência na UTI, ao tempo de permanência hospitalar e à sobrevida do paciente em 3 meses e em 1 ano. Resultados - Inicialmente 205 transplantes foram avaliados. Noventa e quatro foram excluídos e 111 foram incluídos: 71 na era pré-MELD e 40 na era MELD. Os dois grupos foram semelhantes em relação à idade e ao sexo dos doadores e receptores, à etiologia da cirrose e ao tempo de isquemia morna e fria. Os receptores da era MELD apresentaram maior número de pacientes com carcinoma hepatocelular em relação à era pré-MELD (37,5\% vs 16,9\%). Os doentes com carcinoma hepatocelular apresentaram cirrose hepática menos avançada em ambas as eras. O escore do MELD foi igual em ambas as eras. Excluindo aqueles com carcinoma hepatocelular, o escore foi maior na era MELD em relação à era pré-MELD (18,2 vs 15,8). Na era MELD foi observado aumento no número de transplantes realizados em pacientes com cirrose hepática classes A e C de Child-Pugh e redução nos da classe B. As duas eras apresentaram resultados iguais em relação à transfusão de hemácias e tempo de permanência na UTI e permanência hospitalar. A sobrevida em 3 meses e em 1 ano também foi igual: 76\% e 74,6\% na era pré-MELD e 75\% e 70,9\% na era MELD. Conclusão - No centro deste estudo, após a introdução do MELD como critério de seleção de receptores para transplante hepático houve incremento no número de procedimentos em doentes com carcinoma hepatocelular. Excluindo-se esses pacientes, os receptores foram operados em estágios mais avançados da cirrose. Apesar disso, apresentaram a mesma necessidade de transfusão de hemácias, permanência na UTI e permanência hospitalar, e sobrevida em 3 meses e sobrevida em 1 ano.

DESCRITORES - Transplante de fígado. Carcinoma hepatocelular. Cirrose hepática. Listas de espera. Análise de sobrevida.

\section{REFERENCES}

1. Associação Brasileira de Transplante de Órgãos [home page on the internet]. São Paulo: The Association, [cited 2009 Apr 16]. Registro Brasileiro de Transplantes; [about 33 screens]. Avaiable from:http://www.abto.org.br/abtov02/portugues/ populacao/rbt/anoXIV_n2/indexDados.aspx?idCategoria $=2$.

2. Austin MT, Poulose BK, Ray WA, Arbogast PG, Feurer ID, Pinson CW. Mode for end-stage liver disease: did the new liver allocation policy affect waiting list mortality? Arch Surg. 2007;142:1079-85.

3. Bismuth H, Majno PE, Adam R. Liver transplantation for hepatocellular carcinoma. Semin Liver Dis. 1999;19:311-22.

4. Boin IFSF, Leonardi MI, Pinto AO, Leme RSR, Udo E, Stucchi RSB, Soares EC, Leonardi LS. Liver transplant recipients mortality on the waiting list: longterm comparison to Child-Pugh classification and MELD. Transplant Proc. 2004;36:920-2.

5. Brown RS Jr, Kumar KS, Russo MW, Kinkhabwala M, Rudow DL, Harren P, Lobritto $\mathrm{S}$, Emond JC. Model for end-stage liver disease and Child-Turcotte-Pugh score as predictors of pretransplantation disease severity, posttransplantation outcome, and resource utilization in United Network for Organ Sharing status 2A patients. Liver Transpl. 2002;8:278-84.

6. Centers for Disease Control and Prevention. Monthly vital statistics report. Available at: http://www.cdc.gov/nchs/hus.htm. Accessed April 16, 2009.

7. Cheng SJ, Freeman RB, Wong JB. Predicting the probability of progressionfree survival in patients with small hepatocellular carcinoma. Liver Transpl. 2002;8:323-8.

8. Cholongitas E, Marelli L, Shusang V, Senzolo M, Rolles K, Patch D, Burroughs AK. A systematic review of the performance of the model for end-stage liver disease (MELD) in the setting of liver transplantation. Liver Transpl. 2006;12:1049-61.

9. Freeman RB, Wiesner RH, Edwards E, Harper A, Merion R, Wolfe R. Results of the first year of the new liver allocation plan. Liver Transpl. 2004;10:7-15.

10. Freitas AC, Parolin MB, Stadnik L, Coelho JC. Carcinoma hepatocelular: impacto do tempo em lista e das formas de tratamento pré-operatório na sobrevida do transplante de fígado cadavérico na era pré-MELD em um centro no Brasil. Arq Gastroenterol. 2007;44:189-94.

11. Habib S, Berk b, Chang CH, Demetris AJ, Fontes P, Dvorchik I, Eghtesad B, Marcos A, Shakil AO. MELD and prediction of post-liver transplantation survival. Liver Transpl. 2006;12:440-7.

12. Ishigami M, Honda T, Okumura A, Ishikawa T, Kobayashi M, Katano Y, Fujimoto Y, Kiuchi T, Goto H. Use of the Model for End-stage Liver Disease (MELD) score to predict 1-year survival of Japanese patients with cirrhosis and to determine who will benefit from living donor liver transplantation. J Gastroenterol. 2008;43:363-8.
13. Iwatsuki S, Starzl TE, Sheahan DG, Yokoyama Y, Demetris AJ, Todo S, Tzakis AG, Van Thiel DH, Carr B, Selby R, et al. Hepatic resection versus transplantation for hepatocellular carcinoma. Ann Surg. 1991;214:221-8.

14. Jonas S, Bechstein WO, Steinmuller T, Herrman M, Radke C, Berg T, Settmacher U, Neuhauss P. Vascular invasion and histopathologic grading determine outcome after liver transplantation for hepatocellular carcinoma in cirrhosis. Hepatology. 2001;33:1080-6.

15. Kamath PS, Wiesner RH, Malinchoc M, Kremers W, Therneau TM, Kosberg CL, D'Amico G, Dickson ER, Kim WR. A model to predict survival in patients with end-stage liver disease Hepatology. 2001;33:464-70.

16. Kanwal F, Dulai GS, Spiegel BMR, Yee HF, Gralnek IM. A comparison of liver transplantation outcomes in the pre- vs. post-MELD eras. Aliment Pharmacol Ther. 2005;21:169-77.

17. Llovet JM, Fuster J, Bruix J. Intention-to-treat analysis of surgical treatment for early hepatocellular carcinoma: resection versus transplantation. Hepatology. 1999;30:1434-40

18. Malinchoc M, Kamath PS, Gordon FD, Peine CJ, Rank J, ter Borg PC. A model to predict poor survival in patients undergoing transjugular intrahepatic portosystemic shunts. Hepatology. 2000;31:864-71.

19. Mazzaferro V, Regalia E, Doci R, Andreola S, Pulvirenti A, Bozetti F, Montalto F, Ammatuna M, Morabito A, Gennari L. Liver transplantation for the treatment of small hepatocellular carcinoma in patients with cirrhosis. N Engl J Med. 1996;334:693-9.

20. Saab S, Wang V, Ibrahim AB, Durazo F, Han S, Farmer DG, Yersiz H, Morrisey M, Goldstein LI, Ghobrial RM, Busuttil RW. MELD score predicts 1-year patient survival post-orthotopic liver transplantation. Liver Transpl. 2003;9:473-6.

21. Sharma P, Balan V, Hernandez JL, Harper AM, Edwards EB, Rodriguez-Luna H, Byrne T, Vargas HE, Mulligan D, Rakela J, Wiesner RH. Liver transplantation for hepatocellular carcinoma: the MELD impact. Liver Transpl. 2004;10:36-41.

22. United Network for Organ Sharing. 2005 Annual Report of the U.S. Scientific Registry for Transplant Recipients and the Organ Procurement and Transplantation Network. Avaiable at: www.optn.org.

23. Wang VS, Saab S. Liver transplantation in the era of model for end-stage liver disease. Liver International. 2004:24:1-8.

24. Wiesner R, Edwards E, Freeman R, Harper A, Kim R, Kamath P, Kremers W, Lake J, Howard T, Merion RM, Wolfe RA, Krom R. Model for end-stage liver disease (MELD) and allocation of donor livers. Gastroenterology. 2003;124:91-6

25. Yao FY, Bass NM, Ascher NL, Roberts JP. Liver transplantation for hepatocellula carcinoma: lessons from the first year under the Model of End-Stage Liver Disease (MELD) organ allocation policy. Liver Transpl. 2004;10:621-630.

26. Yoo HY, Thuluvath PJ. Short-term post liver transplant survival after the introduction of MELD scores for organ allocation in the United States. Liver Int. 2005;25:536-41.

Received 25/6/2009.

Accepted 6/1/2010 